\title{
NHS locally organised research scheme: regional research committees and the way they work
}

\author{
B T WILLIAMS
}

British Medical fournal, 1978, 1, 85-87

\section{Summary and conclusions}

Regional research committees vary so widely in size, composition, and their methods of judging proposals that the standards of adjudication may also vary. Once the research has started it tends to be poorly monitored, and comparatively little attempt is made to discover whether the inexperienced researcher's ability has been promoted.

Fostering the research spirit entails more than the provision of funds, and some regional health authorities may need to establish more formal ways of supervising and evaluating the research they support.

\section{Introduction}

A scheme to fund research arising from day-to-day medical practice has operated in England and Wales since 1957. Before NHS reorganisation it was known as the decentralised clinical research scheme and was funded by the DHSS but administered locally by regional hospital boards and boards of governors.

After a review by a joint working party of the DHSS, the Welsh Office, and the Medical Research Council (the Black Committee), ${ }^{2}$ which showed that hospital doctors were the major users of the scheme, the DHSS reaffirmed its intention to support a wide range of research in the community and in

Trent Regional Health Authority, Fulwood House, Sheffield S10 3TH B T WILLIAMS, MD, MFCM, specialist in community medicine (information and research) hospital, to foster the research spirit in medicine, and to facilitate the discovery and encouragement of local talent. ${ }^{3}$ Regional health authorities were made responsible for administering the revised scheme in England and the Welsh Office for running a parallel scheme in Wales. The authorities were to be advised by widely representative research committees both generally on the conduct of the scheme and specifically on projects submitted for support. The committees would arrange for less experienced applicants to be helped with formulating their projects. The membership was to represent both the scientific expertise necessary for the assessment of projects and the interests of those trying to promote local research.

This report describes the constitution of regional research committees at the end of 1976, 18 months after the issue of the DHSS circular, and compares the ways in which these committees function. The information was derived from structured interviews with officers of regional health atthorities, the Welsh Office, and DHSS, who were responsible for administering the scheme.

\section{The committees}

By the end of 1976 all but three of the 15 regional research committees had been constituted or reconstituted in response to the DHSS code of practice ${ }^{3}$ (the research committee of the Welsh Office is treated as a regional committee in this report) but the methods of revision varied. Some regional authorities ensured that all their area health authorities were represented; a few emphasised wide professional representation; others concentrated on eminence in research irrespective of the members' geographical or professional ties. Two of the three authorities who had not reformed their committees considered the balance of the existing committees to be adequate. The third proposed to review its research committee in the near future, and, in anticipation of this, the numbers on the existing committee had dwindled to five as members who resigned were not replaced.

The 15 regional research committees included 204 members. The size and composition of the committees are shown in table I. The 
mean number of members per committee was 14 , as was the median number (range 5-17). Over three-quarters were doctors or dentists. Two committees contained no other professionals. Wider professional representation was generally found on the larger committees, though the widest of all was on a committee of 13. Nursing was represented on 11 out of 15 committees, the scientific and technical professions on 10 , while the social sciences were represented on only three. Laymen - that is, individuals not working in the health-care or associated professions (other than through membership of health authorities)sat on eight committees. They were often considered to have particular contributions to offer on ethical issues.

Fourteen of the 15 committees were chaired by doctors and one by a layman. In three English regions the chairmen were also members of their regional health authorities (the Welsh Office committee answers directly to the Secretary of State but functions on behalf of the eight area health authorities in Wales). The regional health authorities' responsibility for administering the scheme was reflected by their representation through lay or professional members on 10 of the English committees. The Welsh committee contained representatives of three area health authorities.

Ninety-three $(46 \%)$ of the 204 members were university academics, most of them (88) professors (table I). The presence of academic staff may be held to enhance the committee's capacity for making objective judgments on scientific merit, but the proportion of academic staff varied greatly among the 15 committees. One 15 -member committee had 13 academics, while a $16-$ member committee had only three.

\section{Assessment of proposals}

In three regions the proposals arising from teaching hospitals were adjudicated by separate committees of the teaching area health authority or of the teaching hospitals themselves. In one case the teaching area research committee was a subcommittee of the regional research committee, augmented by teaching hospital representatives; in the other two cases the teaching hospital committees were entirely separate. In one of these two regions the regional committee reexamined the proposals already passed by the teaching hospital committee. The other two teaching hospital committees were autonomous. In all three regions most of the DHSS allocation for locally organised research was earmarked for projects in the teaching hospitals.

Research proposals reached selection meetings in various stages of development and the process of adjudication varied widely. In some regions regional health authority officers examined the protocols received and in some cases suggested ways in which they might be improved. One regional health authority employed a retired medical professor as research adviser, one of whose functions was to counsel intending applicants on the design of their protocols.

Research committees may augment the information available from a research proposal by seeking the view of a referee or by interviewing the applicant. The smaller committees might be expected to seek additional information more often than the larger ones because of their more limited range of professional representation. But there was no correlation between the size of the committee and the practice of using an independent referee, though five of the eight small committees interviewed some or all of the applicants compared with only one of the seven large ones (table II). Nevertheless, two of the smaller committees neither interviewed nor sought outside advice.

Some committees who used refereeing arranged it in advance of adjudication meetings, either for all proposals or for certain types of proposals, such as relatively costly ones. One regional committee asked the applicant himself to nominate two referees. Other committees sought an independent view only when they were in doubt about a proposal, a final decision being postponed to the next meeting. Similarly with interviewing, some of the committees who interviewed saw all the applicants routinely while others saw only those whose proposals had been deferred for clarification from previous meetings.

A research committee representing all the aspects of NHS practice from which research proposals might arise would be very large. As a result many members might have little to contribute to the discussion of certain proposals. One regional committee, itself already broadly representative, tackled this problem by using specialist advisory subcommittees augmented by experts drawn from a large panel of advisers in combinations appropriate to the nature of the projects under consideration. Even these expert subcommittees interviewed the applicants and occasionally asked for referees' reports.

The practice of eliciting additional information was not related to the amount of information that could be included on the application form, as most application forms were either identical to or based on the model suggested in the DHSS code of practice. ${ }^{3}$

\section{Control of research}

All the regional research committees required interim and final reports of the projects supported. But the extent to which this policy was enforced varied from region to region, as did the method of dealing with the reports received.

Most committees wanted progress reports on the anniversaries of the start of funding. Two regional committees authorised all new grants for only one year initially and required a satisfactory progress report before releasing more funds. The usual pattern, however, was for reports received to be added to the committee meeting papers and considered briefly, if at all, late in the meeting. In some cases it seemed as if all the committee wanted to know was that some research was proceeding. In some regions interim reports normally went no further than the officers administering the scheme or the committee chairman.

Nearly all the committees insisted that a researcher who wanted to extend the duration of his project or incur additional costs, or both, should make out a case for the modification. Occasionally they invoked the help of the original referee. One or two committees permitted the officers to approve such modifications so long as the overall cost and length suggested for the scheme were not exceeded.

TABLE I-Composition of regional research committees in 1976, showing proportions of members who were academics or on regional health authorities

\begin{tabular}{|c|c|c|c|c|c|c|c|c|c|c|c|c|c|c|c|c|c|c|}
\hline \multirow{2}{*}{\multicolumn{3}{|c|}{ Type of member }} & \multicolumn{16}{|c|}{ Region } \\
\hline & & & 1 & 2 & 3 & 4 & 5 & 6 & 7 & 8 & 9 & 10 & 11 & 12 & 13 & 14 & 15 & All \\
\hline \multirow[t]{2}{*}{ 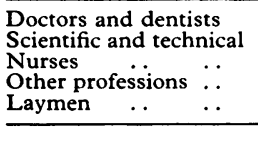 } & $\begin{array}{ll}\because & . . \\
\because & \because . \\
\because & \because . \\
\end{array}$ & $\begin{array}{l}\because \\
\because \\
\because \\
\cdots\end{array}$ & 5 & $\begin{array}{l}8 \\
2\end{array}$ & $\begin{array}{l}9 \\
1 \\
1\end{array}$ & 13 & $\begin{array}{l}7 \\
1 \\
1 \\
3 \\
1\end{array}$ & $\begin{array}{r}11 \\
2 \\
1\end{array}$ & $\begin{array}{r}10 \\
2 \\
1 \\
1\end{array}$ & $\begin{array}{r}12 \\
1\end{array}$ & $\begin{array}{r}13 \\
1 \\
1\end{array}$ & $\begin{array}{r}13 \\
1 \\
1\end{array}$ & $\begin{array}{r}13 \\
1 \\
1\end{array}$ & $\begin{array}{l}9 \\
2 \\
2 \\
1 \\
2\end{array}$ & $\begin{array}{r}11 \\
2 \\
1 \\
2\end{array}$ & $\begin{array}{r}11 \\
3 \\
1 \\
1\end{array}$ & $\begin{array}{r}12 \\
3 \\
1 \\
1\end{array}$ & $\begin{array}{r}157 \\
18 \\
13 \\
6 \\
10\end{array}$ \\
\hline & & Total & 5 & 10 & 11 & 13 & 13 & 14 & 14 & 14 & 15 & 15 & 15 & 16 & 16 & 16 & 17 & 204 \\
\hline \multicolumn{2}{|c|}{$\begin{array}{l}\text { No of members who are also: } \\
\text { Professors and other academics } \\
\text { RHA members .. }\end{array}$} & $\because$. & 2 & $\begin{array}{l}4 \\
1\end{array}$ & $\begin{array}{l}4 \\
2\end{array}$ & $\begin{array}{l}8 \\
1\end{array}$ & $\begin{array}{l}5 \\
1\end{array}$ & 7 & $\begin{array}{l}6 \\
2\end{array}$ & $\begin{array}{l}8 \\
3\end{array}$ & 3 & $\begin{array}{l}6 \\
1\end{array}$ & 13 & $\begin{array}{l}9 \\
4\end{array}$ & $\begin{array}{l}3 \\
3\end{array}$ & $\begin{array}{l}9 \\
3\end{array}$ & $\begin{array}{l}6 \\
3\end{array}$ & $\begin{array}{l}93 \\
24\end{array}$ \\
\hline
\end{tabular}

TABLE II-Interviewing and refereeing practice and size of committee

\begin{tabular}{|c|c|c|c|c|c|c|c|c|c|}
\hline \multirow{2}{*}{$\begin{array}{l}\text { Applicants interviewed: } \\
\text { Applications refereed: }\end{array}$} & \multicolumn{3}{|c|}{ All } & \multicolumn{3}{|c|}{ Some } & \multicolumn{3}{|c|}{ None } \\
\hline & All & Some & None & All & Some & None & All & Some & None \\
\hline 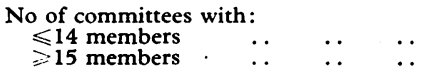 & 1 & 2 & & 1 & 1 & 1 & 2 & $\frac{1}{3}$ & $\begin{array}{l}2 \\
1\end{array}$ \\
\hline
\end{tabular}


In most regions the officers could approve modifications of expenditure, such as using the money granted for materials to support additional clerical or secretarial help, within the total cost limit originally approved for the project.

Final reports usually received closer scrutiny. The commonest practice was for final reports to be circulated with the other committee papers but to be discussed only if members wished to raise particular points. One or two committee chairmen read the reports assiduously and drew the attention of appropriate members of the committee to them. Some regional committees accepted reprints of publications in lieu of a final report. One regional committee organised an annual meeting at which some of those receiving support described the progress or outcome of their projects. Members of the local teaching hospital research committee and the regional research group of the British Medical Association were also invited to attend. This represented the most structured attempt any regional research committee made to evaluate the quality of work supported.

\section{Discussion}

Decentralisation of the management of the NHS locally organised research scheme was intended to enable regional health authorities to develop arrangements best suited to their local circumstances. The variations in the structure and practice of regional research committees suggest, however, that differing standards of adjudication and review may also have resulted. It is difficult to believe, for example, that the smaller committees who neither interview the candidates nor seek the help of expert referees are adequately equipped for judging the entire range of subjects likely to arise. In such circumstances some potential applicants whose disciplines are not represented on the committee may be inhibited from applying.

Compared with the amount of effort put in to ensuring that the research proposed is both meaningful and well designed, that invested in seeing that it is subsequently conducted efficiently and completed successfully is small. A scheme that costs the Exchequer nearly $£ 2 \mathrm{~m}$ a year ${ }^{4}$ and which has welldefined objectives deserves rigorous appraisal.

Assessing whether the scheme has helped to develop an individual's critical faculties is, admittedly, a difficult one. The Black Committee ${ }^{2}$ cited as a measure of success the proportion of projects yielding publications in scientific journals. But the committee found that the yield was greatest among researchers in the teaching hospitals, who were in any case the major users of the scheme. This may imply simply that supporting work in research institutions, where supervision is likely to be best organised, often proves a more profitable investment. As it is, the scheme attempts to attract the inexperienced researcher but provides him with varying degrees of supervision and does little to judge whether the money invested in him is turned to good account. It may be inappropriate to use the procedures of funding bodies such as the Medical Research Council as a yardstick, since such bodies are usually dealing with research workers of known ability.

From 1 April 1978 the DHSS will no longer make a separate allocation to fund the locally organised research scheme. ${ }^{5}$ Instead, regional health authorities will have to allocate funds to research from their global allocations from the DHSS. Most authorities will be forced to consider very carefully how much money they are prepared to invest in fostering the research spirit in the face of other claims on their funds and most will doubtless want to be reassured by their research committees that investing money in inexperienced researchers produces worthwhile results.

It may be difficult to assess whether the individual's critical faculties have been developed, but it should at least be possible to ensure that he is given the fullest opportunity to benefit. This entails more than the mere provision of funds. Universities, for instance, select the most promising students to undertake postgraduate research, but even so they provide many of these students with close academic supervision throughout their period of research. The need for help on the part of inexperienced staff in NHS practice who select themselves for fostering under the locally organised research scheme must be correspondingly greater. The appointment of a regional research adviser and a regional panel of supervisors selected for their experience in research and willingness to offer continuing tutelage to inexperienced investigators may be an important step in ensuring that funds are effectively used. Such arrangements would, of course, have to be applied sensitively so that the learner should feel he was being helped rather than policed. It might underline the authorities' commitment to the aims of the scheme if those who advise, adjudicate, or supervise were paid for the services they give.

I am grateful to the officers of the DHSS, the Regional Health Authorities, and the Welsh Office who provided the information for this study and who bore my persistent querying so courteously. The views expressed here do not necessarily represent those of the Trent Regional Health Authority.

\section{References}

${ }^{1}$ National Health Service Clinical Research, Health Memorandum HM(57) 36. London, Ministry of Health. 1957.

2 Joint Working Party on the Decentralised Clinical Research Scheme in England and Wales, Department of Health and Social Security, Welsh Office, Medical Research Council, Report. London, HMSO, 1974.

${ }^{3}$ NHS Locally Organised Research Scheme HSC(IS)148. London, Department of Health and Social Security, 1975.

${ }^{4}$ Department of Health and Social Security, Annual Report 1975, Cmnd 6565. London, HMSO, 1976.

${ }^{5}$ Devolution of the Locally Organised Research Scheme. Draft Health Circular HC(77). Department of Health and Social Security, 1977.

(Accepted 21 October 1977)
ONE HUNDRED YEARS AGO A case has recently occurred in France, in which the right to examine a dead body without the consent of the relatives and executors has been brought as a question before a court of law. The widow P died in the hospital of Montpellier. Her relatives desired to see the body, and they found that one of the feet had been cut off. The missing foot, at the request of the relatives, was produced and replaced on the leg of the corpse. In explanation, it was stated that the widow $P$ had died of a peculiar disease of great interest in a scientific point of view, and that the Professor of Pathology had found it necessary to make a necropsy and had removed the foot, as it was the seat of an inflammatory lesion the nature of which it was necessary to determine. The relatives of the deceased widow protested against these proceedings, and affirmed that from the date of the death they had given the sister of the ward notice that they would reclaim the dead body. They summoned Professor E, who had conducted the post mortem examination, before the civil tribunal, and claimed from him damages for his interference with the body without their permission. The civil tribunal, in an elaborate judgment, decided against the plaintiffs, and condemned them in the costs of the action, chiefly on the ground that, under an edict of March 1707, the bodies of persons dying in hospitals in which they have received gratuitous attendance shall be at the disposal of the professors for surgical and anatomical examination under certain restrictions. There was, further, no proof that the notice to the ward-sister had been communicated to the professor (Chronique des Tribunaux). As a rule, the hospital authorities in England claim a right to examine the bodies of those who have died in the hospital, not for the purposes of dissection, but to determine and explain the cause of death when this is absent. In some cases, the relatives sign a paper to this effect before the applicant is admitted as a patient. Such a right should in all cases be conceded. (British Medical.fournal, 1878.) 